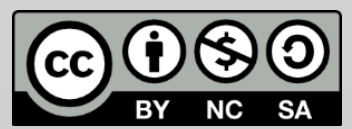

(C) Copyright: The Authors. This article is issued under the terms of the Creative Commons Attribution NonCommercial Share Alike License, which permits use and redistribution of the work provided that the original author and source are credited, the work is not used for commercial purposes and that any derivative works are made available under the same license terms.

\section{Review of Karima Bennoune's Your Fatwa Does Not Apply Here: Untold Stories from the Fight Against Muslim Fundamentalism}

\section{Chitra Nagarajan*}

*Correspondence: chitra.rao.nagarajan@gmail.com

The end of my 2016 was one to remember. I spent New Year's Eve and the days leading up to it interviewing people displaced from Gwoza, a local government area in Nigeria's north east. With a primarily agricultural economy and on the border with Cameroon, Gwoza is multi ethnic and multi religious. People from at least 12 ethnic groups and followers of Christianity, Islam and indigenous religions live side by side, their relationships strengthened by inter-marriage and common ancestors.

The people I spoke with told a common story. They spoke of how, after the extra-judicial killing in 2009 of Mohammad Yusuf, the charismatic founder and leader of Jama'atu Ahlis Sunnah Lida'awati wal Jihad (JAS), commonly known as Boko Haram, and 800 of his followers by security forces, some JAS members escaped to Gwoza. They started preaching to the Muslims of the community, telling them how to behave and to stop mixing with their Christian friends and neighbours. Then they went on to attack, threaten and kill Christians and Muslims who opposed their ideology and actions.

As they tell me about the extent of this violence against those seen as oppositional to JAS ideology and actions, I think of Karima Bennoune's Your Fatwa Does Not Apply Here: Untold Stories from the Fight Against Muslim Fundamentalism (WW Norton \& Company, 2013). Based on almost 300 interviews in nearly 30 countries, Bennoune tells stories of people fighting against Muslim fundamentalism and for peace, justice and human rights. She also tells her own story, opening with the death threats issued against her father, a professor and critic of successive governments and armed fundamentalists, in early 1990s Algeria and interspersing her 
personal reflections throughout the book. As she writes in her introduction, 'the struggle waged in Muslim majority societies against extremism is one of the most important - and overlooked - human rights struggles in the world.'

It's a fight that takes multiple forms. Indeed, many stories told are not of people considered activists in other contexts. Theatre producers, music presenters and playwrights, these are people fighting just to keep illuminated the space for culture and creative expression, even if only for a few hours. The first two chapters are devoted to the role of culture, not surprising given the author is the current United Nations Special Rapporteur in the field of Cultural Rights.

The interplay between defenders of cultural expression and fundamentalism is not often seen in narratives about fundamentalism but this is an important terrain of attacks and resistance as seen by the stories told. The book opens with Faizan Peerzada who, when interviewed by Bennoune in 2010, continued to run the Rafi Peer Theatre Workshop's Youth Performing Festival in Pakistan despite the last festival in 2008 having been bombed. ${ }^{1}$ It goes on to tell the stories of Samia Benkherroubi and Aziz Smati of Bled Music, a music TV show that started at the same time as the rise of fundamentalists in Algeria who were against music. Smati was shot four times by a young man and left for dead. He survived and, together with Benkherroubi, is in exile in Paris.

Smati is not the only person profiled in the book to have been attacked. Maria Bashir, the first woman chief prosecutor in Afghanistan who focuses on cases of corruption and violence against women and girls, receives daily threats, is no longer able to send her children to school and has multiple survived bomb attacks. Sabeen Mahmud, who, in chapter two, talks about $\mathrm{T} 2 \mathrm{~F}$, the café, cultural space and peace organization that she runs, was assassinated on $24^{\text {th }}$ April 2015 while leaving the centre with her mother.

Peerzada, Benkherroubi, Smati, Bashir and Mahmud are just five of the many activists whose stories fill the book. Staff of the Kabul Museum talk 
of how they fought to save priceless historical objects from mujahideen rockets in the late 1980 s only to watch members of the Taliban destroy more than 2,750 pieces in 3 days, hiding some artifacts, 'willing to risk death to keep history alive.' Teachers fight Israeli checkpoints so children in the West Bank can attend a play at the Palestinian National Theatre in East Jerusalem. A documentary filmmaker and photojournalist finally leaves Iran, not after the many times he was arrested and beaten but because he is making a documentary about gay Iranians that he knew 'the government would not like at all.' A member of the Somali community in the US catalyses elders to speak out against recruitment by AI Shabaab and holds a Ramadan Basketball Tournament to give young people something life affirming and fun to do together after his teenage nephew becomes an Al Shabaab fighter. Women human rights defenders protest the flogging of a female journalist for wearing trousers in public in Sudan, fight for the rights of disabled women and girls in Senegal and successfully appeal sharianisation stoning sentences of women for zina in Nigeria. They also march through the streets of Kabul against street harassment, publish a magazine on sex and sexuality for readers across the straight to queer sexual spectrum in Pakistan and organize Women Living Under Muslim Laws (WLUML) to work from a secular perspective and seek to progressively interpret within religion. Journalists in Algeria get out the next day's edition even after bombs hit their newspaper offices killing 18 and wounding 52 colleagues and neighbours while their counterparts in Russia offer media resources to 'the internal and external Muslim world' showing the history of Muslims, Christians and Jews living in peace in their country.

Your Fatwa Does Not Apply Here provides a more nuanced narrative and analysis than that commonly depicted. Concerned with both rising fundamentalism and increasing discrimination against Muslims, Bennoune points out that 'writing about Muslim fundamentalism in this era for an American audience feels like dancing on a minefield.' 'She devotes her final chapter to abuses against human rights committed in the name of 
fighting terrorism. Using examples of the Algerian, Russian and Israeli states, she reminds the reader that 'the battle against fundamentalism is a critical fight for human rights as well as one that has to be guided by human rights.'

She highlights the number of people fighting against fundamentalism in Muslim majority countries who continue to express themselves freely and fight against fundamentalism regardless of whether the world listens or helps. This reality is at odds with common Western narratives and its questions of, 'where are the Muslim voices?' By sharing the stories of people of Muslim heritage that risk their lives to resist fundamentalism, Bennoune flips the question back: why do you not listen to those who speak? Perhaps one of the reasons for this dissonance between rhetoric and reality is that those in the West who demand that 'Muslims speak' are not looking in the right places. They are confined to their own borders and to the 'right kind' of Muslim. The queer Muslim or secular feminist, seen to be infected with Westernisation whether in the West or overseas, is often seen to have lost their 'authenticity.'

Importantly, Bennoune decentres conversations about Muslim fundamentalism, shifting the locus of attention from Europe and North America to the countries where it causes the most pain and suffering. According to the Global Terrorism Index, 68 percent of terrorism related deaths in the world in 2015 took place in just 3 countries: Iraq, Afghanistan and Nigeria. Yet, the news cycle in recent years has been full of attacks in European cities: Berlin, Brussels, Nice, Paris, Zurich. Although what happened in these places and the response to the attacks are important to analyse, there is something intensely problematic about the fact that attacks outside Europe seem not to excite as much interest, even within the countries where they happen. While one group of Muslim fundamentalists killed over a dozen people working at Charlie Hebdo in Paris on 7th January 2015, another group was reported to have killed over 2,000 people in Baga in northeast Nigeria between 3rd and 7th January. 
The fact that so much reporting, discussion and grief does not extend to Muslim fundamentalist attacks outside Europe was brought home to me five days after the November 2015 attacks in Paris. I was on my way to the airport in Kano in northern Nigeria when I got a call that a market we had just passed had been attacked by two bombers, one as young as 11 . While I was trying to call my friends and colleagues from the departure lounge to check they were safe, my eyes fell on the video screen in the corner. Days afterwards, analysts were still discussing what had happened in Paris with only a rolling ticker tape message even acknowledging that attacks had happened in Kano. This was a Nigerian news channel.

Indeed, as the events of 2016 and the first few months of 2017 show us, the fear of Muslim fundamentalism continues to be a strong mobilising factor for discrimination against Muslims in countries across Europe and in the United States of America. This narrative obscures the reality that the impact of Muslim fundamentalism is most felt outside Europe and the USA. As Bennoune writes, far from seeing a clash of civilisations between 'the backwards Muslim world' and 'the enlightened West' as common anti Muslim rhetoric implies, what we are witnessing instead is a clash within civilisations.

Bennoune also highlights the ways in which all sides of the political spectrum in the West often get it wrong. The right justify torture and other human rights violations as part of the war on terror, whipping up racism and prejudice against all Muslims who are seen as a monolithic block of potential terrorists or walking time bombs. On the left, however, refusal to acknowledge the reality of violence and essentialised notions of 'culture,' which are in themselves deeply racist, proliferate. As she forcefully states, 'Muslim fundamentalists are our extreme right' and 'when we talk about Muslim fundamentalism, we have to actually talk about it. It exists. It gravely menaces the human rights of people of Muslim heritage.' The book raises crucial questions about what solidarity looks like in this context and the importance of centring the need to fight 
discrimination against Muslims as well as to resist Muslim fundamentalism.

Your Fatwa Does Not Apply Here may be aimed at a Western audience where it should make an important contribution to ongoing debates but it needs to be read in the countries where the clash within civilisations is most taking place. Unfortunately, it is unlikely to reach many in these countries, a missed opportunity as the story of my colleague and friend Lauratu shows.

Lauratu works to build peace and protect human rights in Nigeria, training journalists to be conflict sensitive so their reporting doesn't create or increase tensions between or within groups. She started this work in the weeks after nine women polio workers were shot and killed in northern Nigeria after a cleric appeared on a popular radio station claiming contaminated medicine caused polio and vaccinations were part of a Western plot to sterilise girls and eliminate the Muslim population. Lauratu is a devout Muslim who prays five times a day without fail and spends much of her weekends learning Arabic and attending Islamic school. She asked to borrow the book when she saw me reading it and sped through it in two days, staying up until the early hours of the morning to do so. She told me just how much she had learned: that people in other countries are experiencing similar dynamics of narrowing theological space; the need to question what religious leaders teach; and the importance of claiming and widening the space for dissent. The book had also started her thinking about her children's Islamic education. Their Islamic school had recently appointed a new director who had fired all the staff and brought in new teachers from Saudi Arabia. In the weeks after reading the book, she mobilised other parents to investigate exactly what interpretations were being taught in the school to make sure their children were not being radicalised.

In the months after this conversation, I have lent my copy to many other friends in Nigeria, particularly activists working in its northeast who 
saw the rise of the fundamentalist movement and its ideology and work in the aftermath of the devastation left by the confrontation between JAS and state security forces. Without fail, it stimulates discussion about the similarities and differences between countries and the lessons Nigeria can learn from what has happened and is happening elsewhere.

I finish writing this review at the Pinnacle Hotel in Maiduguri on a hot Sunday afternoon. Maiduguri, where Yusuf gathered followers, is the home of JAS. The Pinnacle is an unlikely site of resistance against Muslim fundamentalism. It was the location a few years ago where a wedding celebration between two men took place. It wasn't a 'real' wedding of course and the men concerned were arrested but the very fact that there was a celebration of love and commitment between two men in the city that birthed one of the deadliest Muslim fundamentalist groups globally shows the struggle that takes place within Muslim majority societies.

The Pinnacle is also the only place in Maiduguri where I almost feel comfortable uncovering my shoulders in public. Every Sunday afternoon, there is a party by the pool with the latest Naija beats played at loud volume by the enthusiastic DJ. The hotel also has a nightclub that eager clubbers attend, despite it being a likely target of attack. It is strange that going out clubbing equals bravery. But in Maiduguri, the loud drumbeats and the DJ spinning his tunes in the corner feel like an act of resistance. As Faizan Peerzada said, 'If we bow down to the Islamists, then everything is going to be rolled back and they will always have their way, and then there will be nothing. We'll just be sitting in a dark corner.' Your Fatwa Does Not Apply Here is a powerful testament to and celebration of all those who try to keep a light shining in the darkness.

\section{References}


Bennoune, Karima. (2013) Your Fatwa Does Not Apply Here: Untold Stories from the Fight Against Muslim Fundamentalism. New York: W. W. Norton \& Company, Inc.

\section{Notes}

${ }^{1}$ Its headquarters in Lahore were subsequently bombed in 2010. Peerzada died of a heart attack in 2012. His twin brother, Sadaan Peerzada, with whom he had been running the festivals, started holding them again in 2014 in both Lahore and Islamabad.

\section{To cite this article:}

Nagarajan, Chitra. (2017). Review of Karima Bennoune's Your Fatwa Does Not Apply Here: Untold Stories from the Fight Against Muslim Fundamentalism. Feminist Dissent, (2), 201-208. Retrieved from:

http://journals.warwick.ac.uk/index.php/feministdissent/editor/submission Editing/53 